\title{
Elasticity, adhesion and tether extrusion on breast cancer cells provide a signature of their invasive potential
}

Georges Smolyakov, ${ }^{\mathrm{a}, \mathrm{b}}$ Bénédicte Thiebot, ${ }^{\mathrm{c}}$ Clément Campillo*, ${ }^{\mathrm{c}}$ Sid Labdi, ${ }^{\mathrm{c}}$ Childerick Severac, ${ }^{\mathrm{a}}$ Juan Pelta, ${ }^{* \mathrm{c}}$ Étienne Dague ${ }^{* a, b}$

${ }^{a} I T A V$ CNRS, Université de Toulouse, CNRS, Toulouse, France

${ }^{b}$ LAAS-CNRS, Université de Toulouse, CNRS, Toulouse, France

${ }^{c}$ Laboratoire d'Analyse et Modélisation pour la Biologie et l'Environnement LAMBE-CNRS, Université d'Evry, Evry, Université de Cergy-Pontoise, Cergy-Pontoise, France

*Corresponding authors Clément Campillo clement.campillo@univ-evry.fr.Juan Pelta: Juan.Pelta@u-cergy.fror jpelta@univ-evry.fr and Étienne Dague:_edague@laas.fr 


\section{Materials and methods}

\section{Cell culture}

Human breast adenocarcinoma cell lines (SKBR3, MCF7, BT474 and MDA-MB231) were obtained from the American Type Culture Collection (ATCC) and have been previously classified according to their invasive potential in Boyden chamber assay. ${ }^{1,2}$ Tumor formation and metastasis have been studied in vivo in athymic nude mice on these breast cell lines. For SKBR3 cells, 10-week period after tumor cell injection, no palpable tumors were observed in any of the athymic nude mices. ${ }^{3,4}$ At the opposite, primary tumors formed from MCF7, BT474 and MDAMB231 cells. ${ }^{4-6}$ However, MCF7 and BT474 cells have non metastatic abilities contrary to MDA-MB231cells. ${ }^{6,7}$

Cells were grown at $37^{\circ} \mathrm{C}$ in a humidified atmosphere of $5 \% \mathrm{CO}_{2}$ in $\mathrm{T}-75$ culture flasks in RPMI 1640 containing 10 mM Hepes, and Glutamax (Invitrogen), supplemented with 10\% Fetal Calf Serum (FCS, Invitrogen), 50 units/ml Penicillin and $50 \mu \mathrm{g} / \mathrm{ml}$ Streptomycin (Invitrogen). Medium was changed every three days. At subconfluence, cells were dissociated with $0.25 \%$ trypsin, $0.02 \%$ EDTA (Invitrogen).

\section{AFM experiments}

\subsection{Cells preparation}

For AFM cell adhesion assay, two areas were defined by cloning rings in the center of a 10 $\mathrm{cm}^{2}$ TPP Petri dish: the first one to obtain individual adherent cells on fibronectin coating after $24 \mathrm{~h}$, and the second one to prepare non adherent cells on a bovin serum albumin (BSA) coating. Briefly, the previous day, the first area was coated for 1 hour at $37^{\circ} \mathrm{C}$ with $20 \mu \mathrm{g} / \mathrm{ml}$ human fibronectin in phosphate buffered saline (PBS), washed twice with PBS. 15000 cells were then seeded and cultured in complete RPMI medium at $37^{\circ} \mathrm{C}$ in $5 \% \mathrm{CO}_{2} .24 \mathrm{~h}$ later, just before removing the rings for AFM experiments, these cells were washed twice with RPMI without FCS.

The day of AFM measurements, the second area was coated with 1\% BSA in PBS for 1 hour at $37^{\circ} \mathrm{C}$, and washed twice with PBS. New trypsinized cells were incubated for $1 \mathrm{~h} 30$ in complete RPMI medium, then placed in RPMI without FCS, and seeded at 10000 cells on the BSA coating, where cells did not spread for at least 3h. Just before AFM experiments, $2 \mathrm{ml}$ of $\mathrm{CO}_{2}$ independent medium were placed in the Petri dish and the rings were removed. The cells were left to equilibrate in measurement medium at $37^{\circ} \mathrm{C}$ for $30 \mathrm{~min}$ prior to use. 


\subsection{Data acquisition}

The mechanical measurements are done on the CellHesion 200 apparatus (JPK Instruments, Germany), which provides a very large vertical piezoelectric range of $100 \mu \mathrm{m}^{8}$, mounted on a Zeiss inverted optical microscope with a controlled temperature of $37^{\circ} \mathrm{C}$. We use Nanoworld tipless cantilevers with the nominal spring constant of $30 \mathrm{mN} / \mathrm{m}$, the exact value for each cantilever is deduced from the thermal tuning method. ${ }^{9}$ For each cell line from 1 to 3 cantilevers were used.

The cantilevers are covered by concanavalin A $(0.05 \%$ solution for $30 \mathrm{~min})$ in order to promote cell attachment. Such a cell-adherent cantilever is brought into contact with a cell, placed on the BSA-covered zone of Petri dish (providing low adhesion to the substrate). A contact duration of $30 \mathrm{~s}$ at $2.3 \mathrm{nN}$ allowed immobilizing the cell on the cantilever end. The cellmodified cantilever is further used to probe either the FN-covered part of Petri dish or cells adhering on FN. We performed approach-retraction with a ramp size of $50 \mu \mathrm{m}$, cantilever speed of $5 \mu \mathrm{m} / \mathrm{s}$, contact time of $2 \mathrm{~s}$ and force setpoint of $2.3 \mathrm{nN}$.

We performed the AFM experiments at a velocity of $5 \mu \mathrm{m} / \mathrm{s}$. What about the physiological significance of this value on cells? Cancer cells in intravital imaging studies, display a wide range of dynamics and migration modes, through cohesive tissues. Their velocities range from 0.01 to $10 \mu \mathrm{m} / \mathrm{s}$, and the collective migration modes are slower than others (for review ${ }^{10}$ ). In these shear-free environments, cells control their motility in interaction with their environment. Recently, it has been observed in vitro an unexpected tether formation from very invasive cell aggregates in the lack of external applied forces ${ }^{11}$.

In blood vessels, cells are exposed to shear stresses. Experiments using transgenic zebrafish show that the initial arrest of metastatic cells in small vessel $(5-14 \mu \mathrm{m})$ is due to vessel size restrictions; then, after adhesive interactions, an active intravascular migration against blood flow precedes extravasation ${ }^{12}$. In contrast, it has been demonstrated that leukocytes must be slowed by temporary interactions with the vascular endothelium (the rolling) before arrest and extravasation. The velocity of leukocytes when roll along the wall of inflamed venules, was evaluated at $4.8 \mu \mathrm{m} / \mathrm{s}^{13}$, and tether formation is essential for their rolling ${ }^{14}$.

As intravital imaging studies on animal models mainly showed until now a single isolated cell dissemination in epithelial cancers and not grouped in clusters, unlike what is observed in patients $^{10}$, it would be interesting to explore tether formation on patient circulating tumor cells (CTC), single or clustered. 
For every experiment three to four different cells were immobilized on the cantilever, and at least 5 measurements were performed in each case. On the other hand, three membrane tubes from every force curves were analysed, if available, thus providing around 60 tubes analysed for cell-cell contacts in MCF7, BT474 and MDA-MB231 cases. On the contrary, all available tubes were taken into account for SKBR3 cell-cell contacts, as well as for cell-FN interactions for all cell lines, providing in total 8-22 measurements for membrane tubes.

The obtained force curves are analyzed using the JPK Data Processing software. The noise reduction, baseline and tilt corrections are applied for the force curves before calculation of different mechanical and adhesion parameters. The Young modulus is measured by fitting approach curves with the Hertz model ${ }^{15}$ for spherical contact. This model links the deformation $d$ in the direction of the strain of an elastic sphere (radius $R$ ) submitted to an applied force $F: F=$ $4 / 3 * E /\left(1-v^{2}\right) * R^{1 / 2} * d^{3 / 2}$, with $v$ the Poisson ratio, commonly taken as 0.5 . ${ }^{16}$ As the contact is realized between two cells, approximated as identical spheres, they are both mechanically tested. In such a case the total deformation $d=d_{1}+d_{2}$ ( 1 and 2 are related to two cells). In its turn, $E=$ $\left(1 / E_{1}+1 / E_{2}\right)^{-1}$. The same relation is given for the radius: $R=\left(1 / R_{1}+1 / R_{2}\right)^{-1}$. We took $R_{1}=R_{2}=$ $5 \mu \mathrm{m}$. This value is reasonable following the low-adherent cells morphology from obtained optical images. If the cells are adherent to cantilever or substrate, their effective radius (the curvature radius of outer surface of an adherent cell) can increase. ${ }^{17}$ Nevertheless the adherent cells can be still considered like spheres for the correct application of the Hertz model, as their surface displays some curvature which may be described by a finite value of effective radius. As for the absolute modulus value, it has rather weak dependence from the radius $\left(E \sim R^{-1 / 2}\right)$.

The Hertz model does not take adhesion into account. Nevertheless in our experiment the adhesion was several times lower compared to the maximum applied force. In addition we fit the elastic modulus on approach curve, thus neither the maximum contact area was not yet achieved neither the $2 \mathrm{~s}$ contact time was not yet counted. So we can neglect the adhesion contribution to effective force in our case. 


\section{Actin labelling}

10000 cells were seeded in 16-wells Lab-tek $^{\mathrm{TM}}$ chamber slides $\left(0.4 \mathrm{~cm}^{2}\right.$ per chamber $)$ previously coated with $20 \mu \mathrm{g} / \mathrm{ml}$ human fibronectin, and grown two days in complete RPMI medium at $37^{\circ} \mathrm{C}$ in $5 \% \mathrm{CO}_{2}$. For immunostaining procedure, cells were first washed twice with PBS, and after each step described below. Cells were fixed for 15 min with $3.7 \%$ paraformaldehyde, permeabilized for 4 min with $0.2 \%$ Triton X100 and blocked for 30 min with $2 \%$ BSA. Then, the filamentous actin (F-actin) was labelled with phalloidin-TRITC $(4 \mu \mathrm{g} / \mathrm{ml})$ for $1 \mathrm{~h}$ in the dark in humidified atmosphere. Cells were washed three times with PBS to remove unbound molecules, and sandwiched between the glass coverslip and the Lab-tek ${ }^{\mathrm{TM}}$ glass slide, mounted with Gel Mount ${ }^{\mathrm{TM}}$ Aqueous Mounting Medium (Sigma Aldrich). Fluorescent images were taken using a confocal microscope (ZEISS LSM 710).

Table S1. p-values for different cell lines and measured properties.

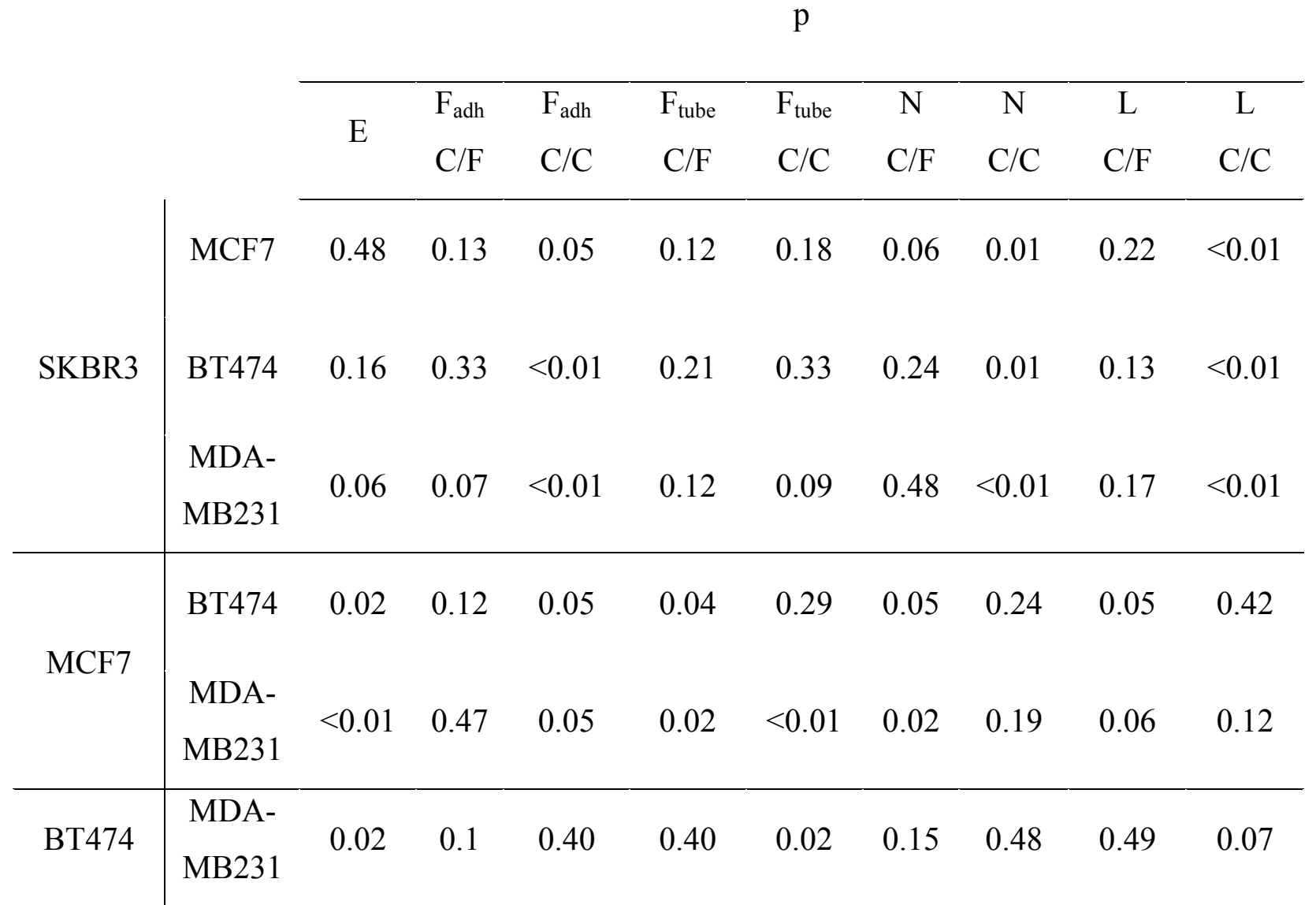

E is Young modulus

$\mathrm{L}$ is separation length

$\mathrm{F}_{\mathrm{adh}}$ is adhesion force

$\mathrm{C} / \mathrm{F}$ refers to cell-to-FN

$F_{\text {tube }}$ is tube rupture force

$\mathrm{C} / \mathrm{C}$ refers to cell-to-cell

$\mathrm{N}$ is number of tethers 


\section{Discussion}

Given the format letters length constraints, some elements of the discussion have been displaced below.

\section{Which receptor would be involved in homotypic interactions of the most invasive cells ?}

Two additional arguments suggest that the higher forces of homotypic cell interactions for the most invasive breast cells might not be due to changes in the expression $\mathrm{N}$ and E-cadherin, but might involve cell adhesion receptor of the immunoglobulin superfamily. Indeed, when cultured in $3 \mathrm{D}$, it has been demonstrated ${ }^{18}$ that MCF7 and BT474 cells form compact spheroids via homophilic Ecadherin-dependent interactions. On the contrary, MDA-MB231 and SKBR3 cells do not form spheroids but exhibited a loose aggregate morphology in 3D culture, primarily by the collagen I / $\beta 1$ integrin interactions with no involvement of E-cadherin. Receptors such as ICAM1, ${ }^{19}$ ALCAM $^{20}$ or L1-CAM ${ }^{21}$ could be good candidates. With regard to ALCAM, it has been demonstrated by AFM that when this receptor could not link to the actin cortex, twice as many tethers are formed ${ }^{22}$. In light of their results, we suggest that, in the most invasive cells, the disorganization of actin, and/or a decrease in the binding of adaptor proteins, bridging the cytoplasmic tail of ALCAM and actin cortex, could promote the production of tethers.

\section{Correlation between actin cytoskeleton organization and tumor cell invasiveness?}

The study of the actin cytoskeleton organization in tumor cells according to their invasiveness is difficult taking into account their morphologies and differences in their spreading. Moreover, especially for cells isolated from various epithelial cancers ( $80 \%$ of cancers), conflicting results have failed to correlate metastatic potential with actin network. ${ }^{23}$ Different strategies are envisaged to overcome these aspects. Recently, it has been established a correlation between the elastic modulus of invasive potential of ovarian cell lines and co-alignment of actin microfilaments. ${ }^{24}$ In order to force the adherent cells to adopt a morphology and an identical spreading degree, cells may be grown on matrix micropaterns, ${ }^{25}$ and a comparative analysis of the cytoskeleton organization could be realized. Moreover, Guck et al ${ }^{26}$ presents a study of the organization of the actin cytoskeleton on non-adherent round cells to compare the amount of actin and its organization in normal and tumor fibroblasts. It appears that the tumor cells have a reduced quantity of polymerized actin. 


\section{References}

(1) Neve, R. M.; Chin, K.; Fridlyand, J.; Yeh , J.; Baehner, F. L.; Fevr, T.; Clark, L.; Bayani, N.; Coppe, J. P.; Tong, F.; Speed, T.; Spellman, P. T.; DeVries, S.; Lapuk, A.; Wang, N. J.; Kuo, W. L.; Stilwell, J. L.; Pinkel, D.; Albertson, D. G.; Waldman, F. M.; McCormick, F.; Dickson, R. B.; Johnson, M. D.; Lippman, M.; Ethier, S.; Gazdar, A.; Gray, J. W. A Collection of Breast Cancer Cell Lines for the Study of Functionally Distinct Cancer Subtypes. Cancer Cell 2006, 10, 515527.

(2) Katchman, B. A.; Ocal, I. T.; Cunliffe, H. E.; Chang, Y. H.; Hostetter, G.; Watanabe, A.; LoBello, J.; Lake, D. F. Expression of Quiescin Sulfhydryl Oxidase 1 Is Associated with a Highly Invasive Phenotype and Correlates with a Poor Prognosis in Luminal B Breast Cancer. Breast Cancer Res. 2013, 15, R28-41.

(3) Fogh, J.; Fogh, J. M.; Orfeo, T. One Hundred and Twenty-Seven Cultured Human Tumor Cell Lines Producing Tumors in Nude Mice. J. Natl. Cancer Inst. 1977, 59(1), 221-226.

(4) Iorns, E.; Hnatyszyn, H. J.; Seo, P.; Clarke, J.; Ward, T.; Lippman, M. The Role of SATB1 in Breast Cancer Pathogenesis. J. Natl. Cancer Inst. 2010, 102(16), 1284-1296.

(5) Lasfargues, E. Y.; Coutinho, W. G.; Redfield, E. S. Isolation of Two Human Tumor Epithelial Cell Lines from Solid Breast Carcinomas. J. Natl. Cancer Inst. 1978, 61(4), 967-978.

(6) Rizwan, A.; Cheng, M.; Bhujwalla, Z. M.; Krishnamachary, B.; Jiang, L.; Glunde, K. Breast Cancer Cell Adhesome and Degradome Interact to Drive Metastasis. npj Breast Cancer 2015, 1, 15017.

(7) Imanishi, H.; Hattori, K.; Wada, R.; Ishikawa, K.; Fukuda, S.; Takenaga, K.; Nakada, K.; Hayashi, J. Mitochondrial DNA Mutations Regulate Metastasis of Human Breast Cancer Cells. PLoS One 2011, 6(8), e23401.

(8) El-Kirat Chatel, S.; Dufrêne, Y. F. Nanoscale Adhesion Forces Between the Fungal Pathogen Candida Albicans and Macrophages. Nanoscale Horizon 2016, 1, 69-74.

(9) Emerson, R. J.; Camesano, T. A. On the Importance of Precise Calibration Techniques for an Atomic Force Microscope. Ultramicroscopy 2006, 106, 413-422.

(10) Clark, A.G.; Vignjevic, D.M. Modes of Cancer Cell Invasion and the Role of the Microenvironment. Curr. Opin. Cell Biol. 2015, 36,13-22.

(11) Beaune, G.; Winnik, F.M.; Brochard-Wyart, F. Formation of Tethers from Spreading Cellular Aggregates. Langmuir 2015, 31(47), 12984-92.

(12) Stoletov, K.; Kato, H.; Zardouzian, E.; Kelber, J.; Yang, J.; Shattil, S.; Klemke, R. Visualizing Extravasation Dynamics of Metastatic Tumor Cells. J. Cell Sci. 2010, 123(Pt 13), 2332-41. 
(13) Dunne, J.L.; Ballantyne, C.M.; Beaudet, A.L.; Ley, K. Control of Leukocyte Rolling Velocity in TNF-Alpha-Induced Inflammation by LFA-1 and Mac-1. Blood 2002, 99(1), 336-41. (14) Sundd, P.; Pospieszalska, M.K.; Ley, K. Neutrophil Rolling at High Shear: Flattening, Catch Bond Behavior, Tethers and Slings. Mol. Immunol. 2013, 55(1), 59-69.

(15) Hertz, H. On the Contact of Elastic Solids. J. reine angew. Math. 1881, 92, 156-171.

(16) Touhami, A.; Nysten B.; Dufrene, Y. F. Nanoscale Mapping of the Elasticity of Microbial Cells by Atomic Force Microscopy. Langmuir 2003, 19, 4539-4543.

(17) Vichare, S.; Inamdar M. M.; Sen, S. Influence of Cell Spreading and Contractility on Stiffness Measurements Using AFM. Soft Matter 2012, 8, 10464-10471.

(18) Ivascu A.; Kubbies, M. Diversity of Cell-Mediated Adhesions in Breast Cancer Spheroids. Int. J. Oncol. 2007, 31(6), 1403-1413.

(19) Rosette, C.; Roth, R. B.; Oeth, P.; Braun, A.; Kammerer, S.; Ekblom J.; Denissenko, M. F. Role of ICAM1 in Invasion of Human Breast Cancer Cells. Carcinogenesis 2005, 26, 943-950. (20) Hein, S.; Müller, V.; Köhler, N.; Wikman, H.; Krenkel, S.; Streichert, T.; Schweizer, M.; Riethdorf, S.; Assmann, V.; Ihnen, M.; Beck, K.; Issa, R.; Jänicke, F.; Pantel K.; MildeLangosch, K. Biologic Role of Activated Leukocyte Cell Adhesion Molecule Overexpression in Breast Cancer Cell Lines and Clinical Tumor Tissue. Breast Cancer Res. Treat. 2011, 129(2), 347-360.

(21) Schröder, C.; Schumacher, U.; Fogel, M.; Feuerhake, F.; Müller, V.; Wirtz, R. M.; Altevogt, P.; Krenkel, S.; Jänicke F.; Milde-Langosch, K. Expression and Prognostic Value of L1-CAM in Breast Cancer. Oncol. Rep. 2009, 22(5), 1109-1117.

(22) Te Riet, J.; Helenius, J.; Strohmeyer, N.; Cambi, A.; Figdor, CG.; Müller DJ. Dynamic Coupling of ALCAM to the Actin Cortex Strengthens Cell Adhesion to CD6. J. Cell Sci. 2014, 127 (Pt 7), 1595-1606.

(23) Ben-Ze'ev, A. The Cytoskeleton in Cancer Cells. Biochim. Biophys. Acta. 1985, 780(3), 197-212.

(24) Xu, W.; Mezencev, R.; Kim, B.; Wang, L.; McDonald, J.; Sulchek, T. Cell Stiffness Is a Biomarker of the Metastatic Potential of Ovarian Cancer Cells. PLoS One 2012, 7, e46609.

(25) Théry, M.; Pépin, A.; Dressaire, E.; Chen Y.; Bornens, M. Cell Distribution of Stress Fibres in Response to the Geometry of the Adhesive Environment. Cell Motil. Cytoskeleton 2006, 63(6), 341-355.

(26) Guck, J.; Schinkinger, S.; Lincoln, B.; Wottawah, F.; Ebert, S.; Romeyke, M.; Lenz, D.; Erickson, H. M.; Ananthakrishnan, R.; Mitchell, D.; Käs, J.; Ulvick S.; Bilby, C. Optical Deformability as an Inherent Cell Marker for Testing Malignant Transformation and Metastatic Competence. Biophys. J. 2005, 88, 3689-3698. 
